
$\$$ Research Square
Preprints are preliminary reports that have not undergone peer review.
They should not be considered conclusive, used to inform clinical practice, or referenced by the media as validated information.

\title{
Urinary Tetrahydrocortisol/Tetrahydrocortisone Ratio at Early Postnatal Period Predict Steroid Dependency and Neonatal Condition in Preterm Infant
}

Ken Nagaya ( $\nabla$ nagaya5p@asahikawa-med.ac.jp )

Asahikawa Medical University: Asahikawa lka Daigaku https://orcid.org/0000-0003-4093-3211

Toshio Okamoto

Asahikawa Medical University: Asahikawa Ika Daigaku

Fumikatsu Nohara

Asahikawa Kosei Hospital

Mitsumaro Nii

Asahikawa Medical College: Asahikawa Ika Daigaku

Aiko Aoyama

Asahikawa Medical University: Asahikawa Ika Daigaku

Tatsutoshi Sugiyama

Asahikawa Medical University: Asahikawa Ika Daigaku

\section{Research Article}

Keywords: Tetrahydrocorotisol/tetrahydrocortisone ratio, 11ß-hydroxysteroid dehydrogenase, preterm infant, adrenal function, glucocorticoid

Posted Date: June 1st, 2021

DOl: https://doi.org/10.21203/rs.3.rs-530936/v1

License: (c) (i) This work is licensed under a Creative Commons Attribution 4.0 International License. Read Full License 


\section{Abstract}

Insufficient adrenal function in preterm infants affects poor neonatal outcome, owing to the immaturity of their adrenal enzyme. While 11ß-hydroxysteroid dehydrogenase (11ßHSD) type 1 and type2 act as gatekeepers for cell steroid action. This study aimed to investigate the effects of early postnatal urinary tetrahydrocortisol/tetrahydrocortisone (F/E) ratio, used as an alternative indicator of $11 \beta \mathrm{HSD}$ activity, in preterm infants on their subsequent clinical course. In 80 preterm infants of $\leq 34$ weeks gestational age admitted to our hospital, urinary F/E ratio was measured within 24 hours of birth. Furthermore, the relationship between this ratio and neonatal outcomes was estimated. Univariate analysis revealed that the high F/E ratio group had significantly higher morbidity in terms of duration of ventilatory support for more than 14 days, hypotension requiring inotropes and hydrocortisone, and symptomatic patent ductus arteriosus. On multivariate analysis, the incidence of hypotension requiring hydrocortisone was higher in the high F/E group, despite the absence of elevated dehydroepiandrosterone, a precursor of cortisol.

Conclusion: The urinary F/E ratio in the early postnatal period in preterm infants may contribute to the understanding of the pathogenesis of infant condition after birth by estimating the amount of local steroid action in the organs.

\section{What Is Known}

- Insufficient adrenal function in preterm infants affects poor neonatal outcome, owing to the immaturity of their adrenal enzyme. While $11 \beta \mathrm{HSD}$ type 1 is a reductase that catalyses the regeneration of active glucocorticoids thereby amplifying the cellular action, $11 \beta \mathrm{HSD}$ type 2 is a high-affinity dehydrogenase that inactivates glucocorticoids. These enzymes act as gatekeepers for cell steroid action.

- The relationship between local steroid action in the organs and neonatal outcomes in preterm infants is not known.

\section{What Is New}

- We revealed that $11 \beta H S D$ 's activity in the organ within 24 hours of birth can affect neonatal outcomes. The F/E ratio at birth is not only related to adrenal immaturity at birth and poor responsiveness of the HPA axis, but also to local steroid action on the organs.

- In order to compensate for the poor responsiveness of the HPA axis, local steroid action may be enhanced, thus reducing $11 \beta \mathrm{HSD}$ type 2 activity. In other words, the low renal activity of $11 \beta \mathrm{HSD}$ type 2 in preterm infants may be due to the effect of glucocorticoids on MR, compensating for the low aldosterone levels.

\section{Introduction}


Glucocorticoid action on target tissues is determined by the hypothalamic-pituitary-adrenal (HPA axis) activation and the density of "nuclear" receptors, and intracellular metabolism by the two isozymes of $11 \beta$-hydroxysteroid dehydrogenase (11ßHSD). While $11 \beta \mathrm{HSD}$ type 1 is a reductase that catalyses the regeneration of active glucocorticoids thereby amplifying the cellular action, 11ßHSD type 2 is a highaffinity dehydrogenase that inactivates glucocorticoids. These enzymes act as gatekeepers for cell steroids [1].

On the other hand, prenatal exposure of the foetus to endogenous and exogenous glucocorticoids promotes foetal organ maturation in exchange for foetal growth [1]. Foetal steroid metabolism is dependent on maternal cortisol passing through the placenta in early pregnancy, and the foetal HPA axis system is immature for steroidogenesis on its own and responds to negative feedback by maternal cortisol. Later in pregnancy, as the maternal cortisol is inactivated to cortisone through slowly activated $11 \beta H S D$ type 2 in the placenta, the foetus is protected from maternal glucocorticoid exposure. Thereafter, the negative feedback is gradually attenuated, the foetal HPA axis is activated, and various organs undergo further maturation [2]. Therefore, the postnatal adrenal function may be affected in preterm infants born when placental $11 \beta H S D$ type 2 activity is insufficient.

However, the role of these systems in the maturation of preterm infants and their influence on morbidity later in life are still not completely understood. This study aimed to investigate the effects of placental and early postnatal $11 \beta \mathrm{HSD}$ s in preterm infants on their subsequent clinical course. The novelty of this study is that it is the first report on the relationship between early postnatal urinary F/E ratio and morbidity in preterm infants.

\section{Materials And Methods}

Eighty preterm infants with a gestational age of $\leq 34$ weeks who were admitted to Asahikawa Medical University hospital, survived for at least one month after birth, and with a consent to participate, were included in this study. This study was performed in accordance with the principles of the Declaration of Helsinki. Approval was granted by the local institutional review board (ethics committees at Asahikawa Medical University), and informed parental consent was obtained before studying all the cases.

Urinary steroid metabolites [cortisol metabolites: tetrahydrocortisol (THF) and tetrahydrocortisone metabolites (allo-THF) and dehydroepiandrosterone (DHEA)] were determined by liquid chromatography/mass spectrometry (LC/MS) using urine samples collected within 24 hours of birth. In adults, the urinary (allo-THF + THF)/THE (F/E) ratio and 11ßHSD type 2 activity were inversely proportional, implying that the higher the F/E ratio, the lower the $11 \beta H S D$ type 2 activity $[3,4]$. Thereafter, the measurements were taken at 1 week $(n=56), 2$ weeks $(n=45), 1$ month $(n=34), 2$ months $(n=19)$, and 3 months $(n=12)$ after birth.

We were able to measure the placental HSD 11b2 mRNA levels in 21 patients. Placental HSD11b2 expression was measured using real-time polymerase chain reaction after delivery of the placenta. To examine whether urine collected within 24 hours of birth would reflect 11ßHSD type 2 activity in the 
placenta during the foetal period, we investigated whether the urinary F/E ratio could be an indicator of placental 11ßHSD type 2 activity, and the relationship between the two in 21 cases in which placental HSD11b2 expression was measured.

Thereafter, we divided the patients into two groups according to the mean urinary F/E ratio and compared the patient characteristics and the incidence of each disease in the neonatal period in the two groups using univariate and multivariate analyses.

Statistical analysis

Pairwise Pearson's product-moment correlation coefficient was used to assess the correlation between the two groups, and the $\rrbracket^{2}$ test and the Wilcoxon signed-rank test were used for comparison between the two groups. Multivariate analysis was performed using logistic regression analysis with adjustment for gestational age, small for gestational age (SGA), and maternal steroid administration as confounders. Statistical analyses were performed using JMP 10.0.2d1 software (SAS Institute Inc., USA).

Our treatment policy and definition of terms

Our hospital is a tertiary perinatal care centre and provides the most critical care for mothers and infants. Chronic pulmonary disease in newborns is defined as a child requiring oxygen for more than 28 days after birth; retinopathy of prematurity was evaluated according to the international classification; periventricular leukomalacia was diagnosed by magnetic resonance imaging of the brain at discharge; and intraventricular haemorrhage was diagnosed by ultrasonography of the brain during admission to the neonatal intensive care unit (NICU). Circulatory management included the use of hydrocortisone 2-3 $\mathrm{mg} / \mathrm{kg} /$ dose for postnatal hypotension with poor response to fluid loading and inotropes, with additional doses as appropriate. Indomethacin was used for symptomatic patent ductus arteriosus (PDA), and surgical treatment (only in two cases) was used if the response was poor.

\section{Results}

In the first 24 hours of life, the urinary steroid metabolite levels were as follows: urinary THF + allo-THF $(\mathrm{ng} / \mathrm{ml}): 48.43 \pm 102.79$, THE $(\mathrm{ng} / \mathrm{ml}): 229.07 \pm 300.55$, and F/E ratio: $0.20 \pm 0.22$ (mean \pm standard deviation). Figure 1 reveals that the F/E ratio was the highest at birth, regardless of the gestational age, and illustrates an immediately decreasing trend with an increasing postnatal age. These trends suggest that local steroid action decreases with age after birth.

Table 1 shows the urinary F/E ratio and urinary THF + allo-THF, THE, DHEA level, and HSD11b2 expression in placenta. Urinary THF + allo-THF and THE were measured in 80 cases, DHEA in 59 cases, and HSD 11b2 expression in the placenta in 21 cases. There was a significant positive correlation between the urinary F/E ratio and urinary THF + allo-THF, but not with urinary DHEA. The relative quantification (RQ) of HSD11b2 expression in the placenta was $1.07 \pm 0.94$; there was no significant correlation with the urinary F/E ratio. 
Most neonatal outcomes were related to normal adrenal gland function. Table 2 shows the incidence of disease in eligible infants in this study. A nationwide survey in Japan revealed that about $4 \%$ of very low birth weight infants require postnatal corticosteroid therapy after 7 days of life. All of them present with at least two of the following five features, including hypotension, oliguria, hyponatraemia, pulmonary oedema, and increased oxygen supplementation [5]. Late-onset circulatory collapse (LCC) represents 'lateonset' transient adrenocortical insufficiency of prematurity. This symptom of prematurity is often reported in Japan $[5,6]$. Indomethacin is generally administered three times in one course for PDA in Japan [7]. Therefore, cases of frequent use were defined as those in which indomethacin was used three or more times in PDA.

To investigate the relationship between morbidity and the F/E ratio in the neonatal period, we compared the patient characteristics between the two groups according to the F/E ratio in Table 3. In the high F/E group, the gestational age was short, and the body size at birth was significantly small. Moreover, there were significantly more SGA infants in the high F/E group. There were no significant differences in other background factors, including prenatal maternal steroid use.

Univariate and multivariate analyses of neonatal morbidity by F/E ratio in the two groups is shown in Table 4. In the univariate analysis, the high F/E group had significantly higher morbidity in respiratory and circulatory conditions. On multivariate analysis adjusted for gestational age, anthropometric status at birth (with or without SGA), prenatal maternal steroid administration which may affect the adrenal function of the infants after birth, and the incidence of hypotension requiring hydrocortisone was higher in the high F/E group.

Receiver operating characteristic (ROC) curve drawn between the urinary F/E ratios at birth for hypotension requiring hydrocortisone is depicted in Figure 2 . The cut-off value was 0.19 with a sensitivity of 0.7692 , specificity of 0.5035 , and area under the curve of 0.7826 .

\section{Discussion}

This is the first report to reveal a relationship between early postnatal urinary F/E ratio and morbidity in preterm infants. Serum cortisol levels are mainly regulated by the HPA axis. However, during development, the foetal adrenal gland is not highly capable of producing its steroids because of the reduced activity of steroid synthetic enzymes, including $3 \beta$-hydroxysteroid dehydrogenase (3ßHSD), and foetal adrenal function is dependent on maternal adrenal function and placenta [8,9]. Maternal glucocorticoid concentrations during this period are approximately 5-10 times higher than those of the foetus, mainly due to the activity of $11 \beta$ HSD type 2 in the placenta, which regulates steroid exposure to the foetus. During development, $11 \beta \mathrm{HSD}$ type 2 is highly expressed in both the foetal and placental tissues [10-13]. However, preterm infants who are born unexpectedly at this time are more likely to have impaired adrenal function, which can be associated with severe neonatal conditions such as hypotension [14-16].

In addition to the regulation of adrenal function by the HPA axis, the intensity of cortisol action in individual cells is precisely controlled by the balance of the activity between the intracellular 
glucocorticoid activating enzyme $11 \beta \mathrm{HSD}$ type 1 and the inactivating enzyme $11 \beta \mathrm{HSD}$ type 2 [17]. In most cells, $11 \beta \mathrm{HSD}$ types 1 and 2 coexist, with $11 \beta \mathrm{HSD}$ type 1 being highly expressed in the liver, adipose tissue, central nervous system, and skeletal muscle, and 11ßHSD type 2 in the renal tubular epithelium, colon, sweat glands, and placenta, which are involved in water and electrolyte metabolism [18]. 11ßHSD types 1 and 2 act as pre-receptor gateways for the glucocorticoid receptor (GR), a system that fine-tunes the intensity of glucocorticoid action on a cell-by-cell basis. Since 11ßHSD type 1 is predominantly responsible for reactivating cortisone to cortisol in vivo, it can be regarded as a local amplification mechanism of glucocorticoid action. In contrast, 11ßHSD type 2 is an enzyme that inactivates cortisol to cortisone and is expressed predominantly in the distal nephron in adults, suppressing the binding of cortisol to the mineralocorticoid receptor (MR) in the kidney. Cortisol also acts as a ligand for the MR and has a comparable affinity to aldosterone. Apparent mineralocorticoid excess syndrome (AME; OMIM \#218030) is caused by an abnormality in 11ßHSD type 2, which fails to inactivate cortisol in the kidney and binds to the MR, resulting in excessive activation of the MR by glucocorticoids, leading to AME $[3,19]$.

The urinary F/E ratio is used as an alternative indicator of renal 11ßHSD type 2 activity in the diagnosis of AME [3]. However, in foetuses and neonates, renal 11ßHSD type 2 activity is less than one-tenth of that in adults, and unlike in adults, the foetus converts cortisol to cortisone in many tissues [11]. Therefore, the urinary $\mathrm{F} / \mathrm{E}$ ratio in the neonatal period may reflect the total activity of $11 \beta \mathrm{HSD}$ types 1 and 2 not only in the kidneys, but also in the whole neonatal body and may be an indicator of local steroid action in the whole body. $11 \beta \mathrm{HSD}$ s are expressed in many foetal cells during this period and, in general, prenatal exposure to endogenous and exogenous glucocorticoids promotes maturation of foetal organs in exchange for overall growth $[20,21]$. Glucocorticoid exposure in the cells is precisely controlled for each tissue maturation. We hypothesised that urinary F/E ratios at birth could be used to infer local glucocorticoid effects, organ maturation, and adrenal maturation after birth, and to predict the impact on subsequent morbidity.

In the univariate analysis of this study, a higher urinary F/E ratio in the early postnatal period was associated with a longer duration of ventilatory care and a higher incidence of chronic lung disease, symptomatic PDA, and hypotension requiring inotropes and steroids after birth. The results of this study suggest that the high urinary F/E ratio (i.e. low $11 \beta H S D$ type 2 activity) in preterm infants in the early postnatal period is related to the reduced activity of local steroids in each organ. The fact that hypotension in the early postnatal period requiring steroids was significantly more common in the group with a higher $F / E$ ratio in multivariate analysis supports this conjecture. Since several respiratory and circulatory conditions were affected as revealed by the univariate analysis, it was suggested that the F/E ratio in early neonates may estimate the maturation of each organ of the neonate and the maturation of the HPA axis. The present results indicate that there is no correlation between the F/E ratio in the early postnatal period and placental HSD11b2 expression. Therefore, the relationship between each estimation was independent, and the degree of maternal glucocorticoid transfer had less effect on the HPA axis in infants. In other words, it should be noted that the regulation of the intensity of glucocorticoid action in the local organs of the neonate can affect the infant's condition. Based on these results, we speculate the following pathophysiology. 
First, there may be inadequate glucocorticoid production in response to the infant's medical condition after birth, resulting in relative adrenal insufficiency, which may enhance the action of local glucocorticoids $[14,22]$. Previous reports have indicated that insufficient adrenal function in preterm infants causes poor neonatal outcomes because of the immaturity of adrenal enzymes in preterm infants [14]. However, the absence of a correlation between the F/E ratio and DHEA, a precursor of cortisol, suggests that the $\mathrm{F} / \mathrm{E}$ ratio at birth is not only related to adrenal immaturity at birth, but also to poor responsiveness of the HPA axis. The fact that urinary F/E showed an immediate decrease with postnatal age in the present study, similar to that reported by Midgley et al. [23], may be because of the enhanced local action that becomes unnecessary as the HPA axis matures. In order to compensate for the poor responsiveness of the HPA axis, local steroid action may be enhanced, thus reducing 11ßHSD type 2 activity. Heckmann et al. reported similar actions in cardiac paediatric surgery. Our results are in agreement with that of these studies [24].

Second, we considered the immaturity of the regulation of 11ßHSD type 2 activity in the kidney. As mentioned above, in the kidney, local 11ßHSD type 2 inactivates glucocorticoids, which are also ligands for MR, preventing them from incorrectly activating the MR. However, it has been reported that preterm infants have a low capacity to produce aldosterone but a high expression of MR [25-27]. The low renal activity of $11 \beta \mathrm{HSD}$ type 2 in preterm infants (one-tenth of that in adults) may be due to the effect of glucocorticoids on the MR, compensating for the low aldosterone levels. Hypotension requiring steroids in the early postnatal period in preterm infants is not accompanied by classical adrenal insufficiency findings such as hypoglycaemia, hyponatraemia, and hyperkalaemia, while small doses of hydrocortisone are effective [14]. This phenomenon may be due to the effect of glucocorticoids on MR in the kidneys.

In the present study, the relationship between placental 11ßHSD type 2 gene expression and neonatal morbidity could not be examined due to the small number of samples. The urinary $\mathrm{F} / \mathrm{E}$ ratio in the early postnatal period did not correlate with placental $11 \beta \mathrm{HSD}$ type 2 gene expression and did not reflect placental $11 \beta \mathrm{HSD}$ type 2 activity, suggesting that the urinary F/E ratio can be evaluated independently without placental 11ßHSD type 2 activity. The urinary F/E ratio is the most convenient means of measuring the activity of $11 \beta \mathrm{HSD}$ types 1 and 2 . However, there are several caveats to the use of these urinary steroid ratios: 1 ) it is the sum of both $11 \beta$-HSD activities; 2 ) the ratio is also influenced by $5 a-$ and $5 \beta$-reductase activities; and 3 ) the ratio does not represent a tissue-specific effect but reflects a systemic effect.

In conclusion, the premature infants suffered several conditions, especially respiratory and circulatory problems, did not only show an increased adrenal stress response, but also an enhancement of glucocorticoid action in local organs due to the reduction in cortisol inactivation. The urinary F/E ratio in the early postnatal period in preterm infants contribute to the understanding of the pathogenesis of the infant condition after birth by estimating the amount of local steroid action in the organs.

\section{Abbreviations}


AME: apparent mineralocorticoid excess syndrome, DHEA: dehydroepiandrosterone, GR: glucocorticoid receptor, GS/MS: gas chromatography/mass spectrometry, HPA axis: hypothalamic-pituitary-adrenal axis, LC/MS: liquid chromatography/mass spectrometry, MR: mineralocorticoid receptor, NICU: neonatal intensive care unit, PDA: patent ductus arteriosus, ROC curve: receiver operating characteristic curve, RQ: relative quantification, SGA: small for gestational age, THE: tetrahydrocortisone, THF: tetrahydrocortisol,

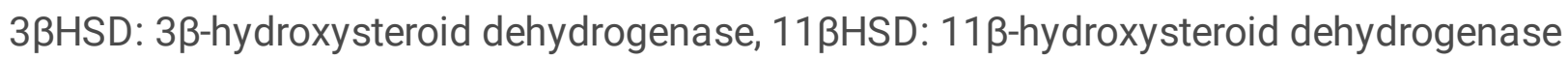

\section{Declarations}

Funding: The authors did not receive support from any organization for the submitted work.

Conflicts of interest/Competing interests: The authors have no relevant financial or non-financial interests to disclose.

Availability of data and material: Not applicable

Code availability: Not applicable

\section{Authors' contributions:}

All authors contributed to the conception and design of the study. Material preparation, data collection, and analysis were performed by Toshio Okamoto and Fumikatsu Nohara. The first draft of the manuscript was written by Ken Nagaya, and all authors commented on the previous versions of the manuscript. All authors read and approved the final manuscript. Ken Nagaya contributed to the conception of work, and the acquisition, analysis, and interpretation of data.

Ethics approval: The study was approved by the local institutional review board (ethics committees at Asahikawa Medical University).

Consent to participate: Informed parental consent was obtained before studying all cases.

Consent for publication: Informed parental consent was obtained before studying all cases.

Acknowledgements: This work was supported by KAKENHI (24591596) and Grant-in-Aid for Scientific Research (C) by the Japan Society for the Promotion of Science (JSPS).

\section{References}

1. Chapman K, Holmes M, Seckl J (2013) 11ß-hydroxysteroid dehydrogenases: intracellular gatekeepers of tissue glucocorticoid action. Physiol Rev 93:1139-1206.

https://doi.org/10.1152/physrev.00020.2012

2. Seckl JR (2001) Glucocorticoid programming of the fetus; adult phenotypes and molecular mechanisms. Molecular and Cellular Endocrinology 185:61-71. https://doi.org/10.1016/S0303- 
7207(01)00633-5

3. Mune T, Rogerson FM, Nikkilä H, Agarwal AK, White PC (1995) Human hypertension caused by mutations in the kidney isozyme of 11 beta-hydroxysteroid dehydrogenase. Nat Genet 10:394-399. https://doi.org/10.1038/ng0895-394

4. Palermo M, Shackleton $\mathrm{CH}$, Mantero F, Stewart PM (1996) Urinary free cortisone and the assessment of 11 beta-hydroxysteroid dehydrogenase activity in man. Clin Endocrinol (Oxf) 45:605-611. https://doi.org/10.1046/j.1365-2265.1996.00853.x

5. 5. Masumoto K, Kusuda S, Aoyagi H, Tamura Y, Obonai T, Yamasaki C, Sakuma I, Uchiyama A, Nishida H, Oda S, et al (2008) Comparison of serum cortisol concentrations in preterm infants with or without late-onset circulatory collapse due to adrenal insufficiency of prematurity. Pediatr Res 63:686-690. https://doi.org/1203/PDR.0b013e31816c8fcc

6. lijima S (2019) Late-onset glucocorticoid-responsive circulatory collapse in premature infants. Pediatrics and Neonatology 60, 603-610. https://doi.org/10.1016/j.pedneo.2019.09.005

7. Itabashi K, Ohno T, Nishida H (2003) Indomethacin responsiveness of patent ductus arteriosus and renal abnormalities in preterm infants treated with indomethacin. J Pediatr 143:203-207.https://doi: 10.1067/S0022-3476(03)00303-2.

8. Nykänen P, Heinonen K, Riepe FG, Sippell WG, Voutilainen R (2010) Serum concentrations of adrenal steroids and their precursors as a measure of maturity of adrenocortical function in very premature newborns. Horm Res Paediatr 74:358-364. https://doi.org/10.1159/000314970

9. 9. Parker CR, Faye-Petersen O, Stankovic AK, Mason JI, Grizzle WE (1995) Immunohistochemical evaluation of the cellular localization and ontogeny of 3 beta-hydroxysteroid dehydrogenase/delta 54 isomerase in the human fetal adrenal gland. Endocr Res 21:69-80. https://doi.org/10.3109/07435809509030422

10. Martinerie L, Pussard E, Meduri G, Delezoide AL, Boileau P, Lombès M (2012) Lack of renal 11 betahydroxysteroid dehydrogenase Type 2 at birth, a targeted temporal window for neonatal glucocorticoid action in human and mice. PLOS ONE 7:e31949. https://doi.org/10.1371/journal.pone.0031949

11. Stewart PM, Murry BA, Mason JI (1994) Type 211 beta-hydroxysteroid dehydrogenase in human fetal tissues. J Clin Endocrinol Metab 78:1529-1532. https://doi.org/10.1210/jcem.78.6.8200959

12. Brown RW, Chapman KE, Kotelevtsev Y, Yau JLW, Lindsay RS, Brett L, Leckie C, Murad P, Lyons V, Mullins JJ, Edwards CRW, Seckl JR (1996) Cloning and production of antisera to human placental 11 $\beta$-hydroxysteroid dehydrogenase type 2. Biochem J 313:1007-1017. https://doi.org/10.1042/bj3131007

13. Blasco MJ, López Bernal A, Turnbull AC (1986) 11 beta-Hydroxysteroid dehydrogenase activity of the human placenta during pregnancy. Horm Metab Res 18:638-641. https://doi.org/10.1055/s-20071012393

14. Ng PC (2016) Adrenocortical insufficiency and refractory hypotension in preterm infants. Arch Dis Child Fetal Neonatal Ed 101:F571-F576. http://dx.doi.org/10.1136/archdischild-2016-311289 
15. Challis JR, Sloboda D, Matthews SG, Holloway A, Alfaidy N, Patel FA, Whittle W, Fraser M, Moss TJ, Newnham J (2001) The fetal placental hypothalamic-pituitary-adrenal (HPA) axis, parturition and postnatal health. Mol Cell Endocrinol 185:135-144. https://doi.org/10.1016/S0303-7207(01)00624-4

16. Huysman MWA, Hokken-Koelega ACS, De Ridder MAJ, Sauer PJJ (2000) Adrenal function in sick very preterm infants. Pediatr Res 48:629-633. https://doi.org/10.1203/00006450-200011000-00013

17. Walker BR (2007) Extra`adrenal regeneration of glucocorticoids by 11 beta-hydroxysteroid dehydrogenase type 1: physiological regulator and pharmacological target for energy partitioning. Proc Nutr Soc 66:1-8. https://doi.org/10.1017/S002966510700523X

18. Morton NM, Seckl JR (2008) 11-beta'hydroxysteroid dehydrogenase type 1 and obesity. Front Horm Res 36:146-164. https://doi.org/10.1159/000115363

19. Dave-Sharma S, Wilson RC, Harbison MD, Newfield R, Azar MR, Krozowski ZS, Funder JW, Shackleton CHL, Bradlow HL, Wei JQ, Hertecant J, Moran A, Neiberger RE, Balfe JW, Fattah A, Daneman D, Akkurt HI, De Santis C, New MI (1998) Examination of genotype and phenotype relationships in 14 patients with apparent mineralocorticoid excess. J Clin Endocrinol Metab 83:2244-2254. https://doi.org/10.1210/jcem.83.7.4986

20. Cottrell EC, Seckl JR, Holmes MC, Wyrwoll CS (2014) Foetal and placental 11ß-HSD2: a hub for developmental programming. Acta Physiol (Oxf) 210:288-295. https://doi.org/10.1111/apha.12187

21. Challis JRG, Connor K (2009) Glucocorticoids, $11 \beta$-Hydroxysteroid dehydrogenase: mother, Fetus, or Both? Endocrinology 150:1073-1074. https://doi.org/10.1210/en.2008-1577

22. 22. Boonen $E$, Vervenne $H$, Meersseman $P$, Andrew $R$, Mortier $L$, Declercq $P E$, Vanwijngaerden $Y M$, Spriet I, Wouters PJ, Perre SV, Langouche L, et al (2013) Reduced Cortisol Metabolism during Critical Illness. N Engl J Med 368:1477-1488. https://org/10.1056/NEJMoa1214969

23. Midgley PC, Holownia P, Smith J, Moore M, Russell K, Oates N, Shaw JCL, Honour JW (2001) Plasma cortisol, cortisone and urinary glucocorticoid metabolites in preterm infants. Biol Neonate 79:79-86. https://doi.org/10.1159/000047071

24. Heckmann M, d'Uscio CH, Steckel H, Neuhaeuser C, Bodeker RH, Thul J, Schranz D, Frey BM (2014) Reduction in cortisol inactivation is part of the adrenal stress response to cardiac and noncardiac pediatric surgery: A prospective study using gas chromatography-mass spectrometry analysis. Horm Metab Res 46:677-684. https://doi.org/10.1055/s-0034-1375650

25. Martinerie L, Pussard E, Yousef N, Cosson C, Lema I, Husseini K, Mur S, Lombès M, Boileau P (2015) Aldosterone-signaling defect exacerbates sodium wasting in very preterm neonates: the Premaldo study. J Clin Endocrinol Metab 100:4074-4081. https://doi.org/10.1210/jc.2015-2272

26. Travers $S$, Martinerie L, Boileau P, Lombès M, Pussard E (2018) Alterations of adrenal steroidomic profiles in preterm infants at birth. Arch Dis Child Fetal Neonatal Ed 103:F143-F151. http://dx.doi.org/10.1136/archdischild-2016-312457

27. Hirasawa G, Sasano H, Suzuki T, Takeyama J, Muramatu Y, Fukushima K, Hiwatashi N, Toyota T, Nagura H, Krozowski ZS (1999) 11ß-Hydroxysteroid dehydrogenase Type 2 and mineralocorticoid 
receptor in Human Fetal Development. J Clin Endocrinol Metab 84:1453-1458.

https://doi.org/10.1210/jcem.84.4.5615

28. Caulfield MP, Lynn T, Gottschalk ME, Jones KL, Taylor NF, Malunowicz EM, Shackleton CHL, Reitz RE, Fisher DA (2002) The diagnosis of congenital adrenal hyperplasia in the newborn by gas chromatography/mass spectrometry analysis of random urine specimens. J Clin Endocrinol Metab 87:3682-3690. https://doi.org/10.1210/jcem.87.8.8712

29. Papile LA, Burstein J, Burstein R, Koffler H (1978) Incidence and evolution of subependymal and intraventricular hemorrhage: a study of infants with birth weights less than $1500 \mathrm{gm}$. J Pediatr 92:529-534. https://doi.org/10.1016/S0022-3476(78)80282-0

\section{Tables}

Table.1: The correlation between urinary (alloTHF + THF), THE, DHEA and placental HSD11b2 mRNA at birth

\begin{tabular}{|llll|}
\hline vs. urinary (alloTHF + THF)/THE & $\mathrm{n}$ & $\mathrm{r}$ & $\mathrm{p}$ \\
\hline Urinary alloTHF + THF* & 80 & 0.37 & $<0.001$ \\
\hline Urinary THE & 80 & 0.04 & 0.7 \\
\hline Urinary DHEA & 59 & -0.1 & 0.5 \\
\hline Placental HSD11b2 mRNA & 21 & -0.06 & 0.8 \\
\hline
\end{tabular}

THE: tetrahydrocortisone, THF: tetrahydrocortisol; DHEA: dehydroepiandrosterone

Table.2: The short-term outcome in neonatal period 


\begin{tabular}{|lll|}
\hline & \multicolumn{2}{l|}{ Total $=80$} \\
\hline & $n$ & $\%$ \\
\hline RDS & 36 & 45.6 \\
\hline CLD & 31 & 39.2 \\
\hline Mechanical ventilation days $>$ 14 days & 30 & 38.0 \\
\hline PC for ROP & 18 & 23.7 \\
\hline IVH (any grade) & 16 & 20.0 \\
\hline IVH $\geq$ grade 3 & 2 & 2.5 \\
\hline PVL & 10 & 12.7 \\
\hline NEC & 3 & 3.8 \\
\hline Inotropes use & 30 & 38.0 \\
\hline Glucocorticoid use for hypotension & 13 & 16.5 \\
\hline PPHN & 2 & 2.5 \\
\hline LCC & 3 & 3.8 \\
\hline Symptomatic PDA & 19 & 24.1 \\
\hline Indomethacin use for PDA $>3$ times & 17 & 21.5 \\
\hline PDA ligation & 1 & 1.3 \\
\hline Feeding establishment $>$ 14 days of life & 8 & 10.4 \\
\hline Sepsis & 0 & 0.0 \\
\hline
\end{tabular}

IVH grade was subdivided by grading system proposed by Papile et al [29]. PPHN was defined by echography, as right to left shunt on ductus arteriosus and foramen ovale. LCC was diagnosed according to clinical criteria by Masumoto, et al [5]. Symptomatic PDA was defined as hemodynamically affected and requiring treatment.

RDS: respiratory distress syndrome, CLD: chronic lung disease (oxygen requirement at 28 days of life), PC: retinal photocoagulation, ROP: retinopathy of prematurity, IVH: intraventricular haemorrhage, PVL: periventricular leukomalacia, NEC: necrotizing enterocolitis, PPHN: persistent pulmonary hypertension of newborn, LCC: late onset collapse of circulation, PDA: patent ductus arteriosus

Table.3: The comparison of characteristics between high and low tetrahydrocortisol/tetrahydrocortisone (F/E) ratio 


\begin{tabular}{|lllll|}
\hline & Low F/E (53) & High F/E (27) & RR (95\% Cl) & $\mathrm{p}$ \\
\hline Gestational age (wks) & $30.3 \pm 3.4$ & $29.1 \pm 3.6$ & $\mathrm{~ns}$ \\
\hline Birth weight (g)* & $1490.1 \pm 538.1$ & $1170.8 \pm 519.2$ & 0.01 \\
\hline Birth weight SD* & $0.06 \pm 0.6$ & $-0.5 \pm 1.1$ & & $<.01$ \\
\hline Birth height (cm)* & $37.9 \pm 4.5$ & $35.3 \pm 4.8$ & & 0.02 \\
\hline Birth height SD & $-0.7 \pm 0.9$ & $-1.0 \pm 1.2$ & & 0.1 \\
\hline Birth head circumference (cm) & $28.1 \pm 4.1$ & $26.8 \pm 3.8$ & & 0.2 \\
\hline Birth head circumference SD & $0.3 \pm 1.2$ & $0.1 \pm 1.4$ & & $\mathrm{~ns}$ \\
\hline SGA* & 0 & 7 & 0.001 \\
\hline Male & 26 & 13 & $1.02(0.63-1.66)$ & $\mathrm{ns}$ \\
\hline Primi-para & 25 & 13 & $1.00(0.65-1.55)$ & $\mathrm{ns}$ \\
\hline Initiation of labor & 28 & 14 & $0.80(0.60-1.05)$ & $\mathrm{ns}$ \\
\hline Cesarean section & 46 & 18 & $1.11(0.77-1.61)$ & $\mathrm{ns}$ \\
\hline Prenatal steroid use for mother & 30 & 17 & $1.25(0.55-2.85)$ & $\mathrm{ns}$ \\
\hline Intrauterine infection & 11 & 7 & $2.38(0.89-6.36)$ & 0.1 \\
\hline HDP & 6 & 7 & $\mathrm{~ns}$ \\
\hline Mother's age & $31.8 \pm 5.2$ & $31.4 \pm 5.9$ & & $\mathrm{~ns}$ \\
\hline
\end{tabular}

SD: standard deviation, SGA: small for gestational age, HDP: hypertensive disorders of pregnancy

Table.4: The comparison of outcome in neonatal period between high and low tetrahydrocortisol/tetrahydrocortisone (F/E) ratio 


\begin{tabular}{|c|c|c|c|c|c|c|}
\hline & $\begin{array}{l}\text { Low F/E } \\
\text { (56) }\end{array}$ & $\begin{array}{l}\text { High F/E } \\
\text { (27) }\end{array}$ & $\begin{array}{l}\text { Crude RR } \\
(95 \% \mathrm{Cl})\end{array}$ & p & $\begin{array}{l}\text { Adjusted OR } \\
\text { (95\% Cl) }\end{array}$ & $\mathbf{p}$ \\
\hline RDS & 24 & 12 & $\begin{array}{l}1.02(0.61- \\
1.70)\end{array}$ & ns & $\begin{array}{l}0.63(0.18- \\
2.07)\end{array}$ & ns \\
\hline CLD & 17 & 14 & $\begin{array}{l}1.68(0.99- \\
2.85)\end{array}$ & 0.09 & $\begin{array}{l}0.95(0.07- \\
13.24)\end{array}$ & ns \\
\hline $\begin{array}{l}\text { Mechanical ventilation days } \\
>14 \text { days }^{\star}\end{array}$ & 16 & 14 & $\begin{array}{l}1.78(1.04- \\
3.07)\end{array}$ & 0.04 & $\begin{array}{l}1.70(0.21- \\
16.14)\end{array}$ & ns \\
\hline PHC for ROP & 9 & 9 & $\begin{array}{l}2.04(0.93- \\
4.50)\end{array}$ & 0.07 & $\begin{array}{l}2.00(0.26- \\
20.96)\end{array}$ & ns \\
\hline IVH (any grade) & 6 & 10 & $\begin{array}{l}1.67(0.67- \\
4.16)\end{array}$ & ns & $\begin{array}{l}1.31(0.31- \\
5.34)\end{array}$ & ns \\
\hline PVL & 6 & 4 & $\begin{array}{l}1.36(0.42- \\
4.40)\end{array}$ & ns & $\begin{array}{l}0.73(0.11- \\
3.84)\end{array}$ & ns \\
\hline Inotoropes use* & 16 & 14 & $\begin{array}{l}1.78(1.04- \\
3.07)\end{array}$ & 0.04 & $\begin{array}{l}3.43(0.53- \\
28.71)\end{array}$ & ns \\
\hline $\begin{array}{l}\text { Glucocorticoid use for } \\
\text { hypotension** }\end{array}$ & 4 & 9 & $\begin{array}{l}4.59(1.56- \\
13.51)\end{array}$ & $\begin{array}{l}< \\
0.01\end{array}$ & $\begin{array}{l}7.25(1.24- \\
56.39)\end{array}$ & $\dot{0} .03$ \\
\hline Symptomatic PDA* & 8 & 11 & $\begin{array}{l}2.80(1.28- \\
6.12)\end{array}$ & 0.01 & $\begin{array}{l}3.85(0.97- \\
16.48)\end{array}$ & 0.06 \\
\hline $\begin{array}{l}\text { Indomethacin use for PDA > } \\
3 \text { times }\end{array}$ & 9 & 8 & $\begin{array}{l}1.81(0.79- \\
4.15)\end{array}$ & ns & $\begin{array}{l}1.61(0.37- \\
6.97)\end{array}$ & ns \\
\hline $\begin{array}{l}\text { Feeding establishment } \geq \\
14 \text { days of life }\end{array}$ & 3 & 5 & $\begin{array}{l}3.27(0.85- \\
12.63)\end{array}$ & ns & $\begin{array}{l}2.10(0.34- \\
13.40)\end{array}$ & ns \\
\hline
\end{tabular}

RDS: respiratory distress syndrome, CLD: chronic lung disease (oxygen requirement at 28 days of life), PHC: retinal photocoagulation, ROP: retinopathy of prematurity, IVH: intraventricular haemorrhage, PVL: periventricular leukomalacia, PDA: patent ductus arteriosus

\section{Figures}




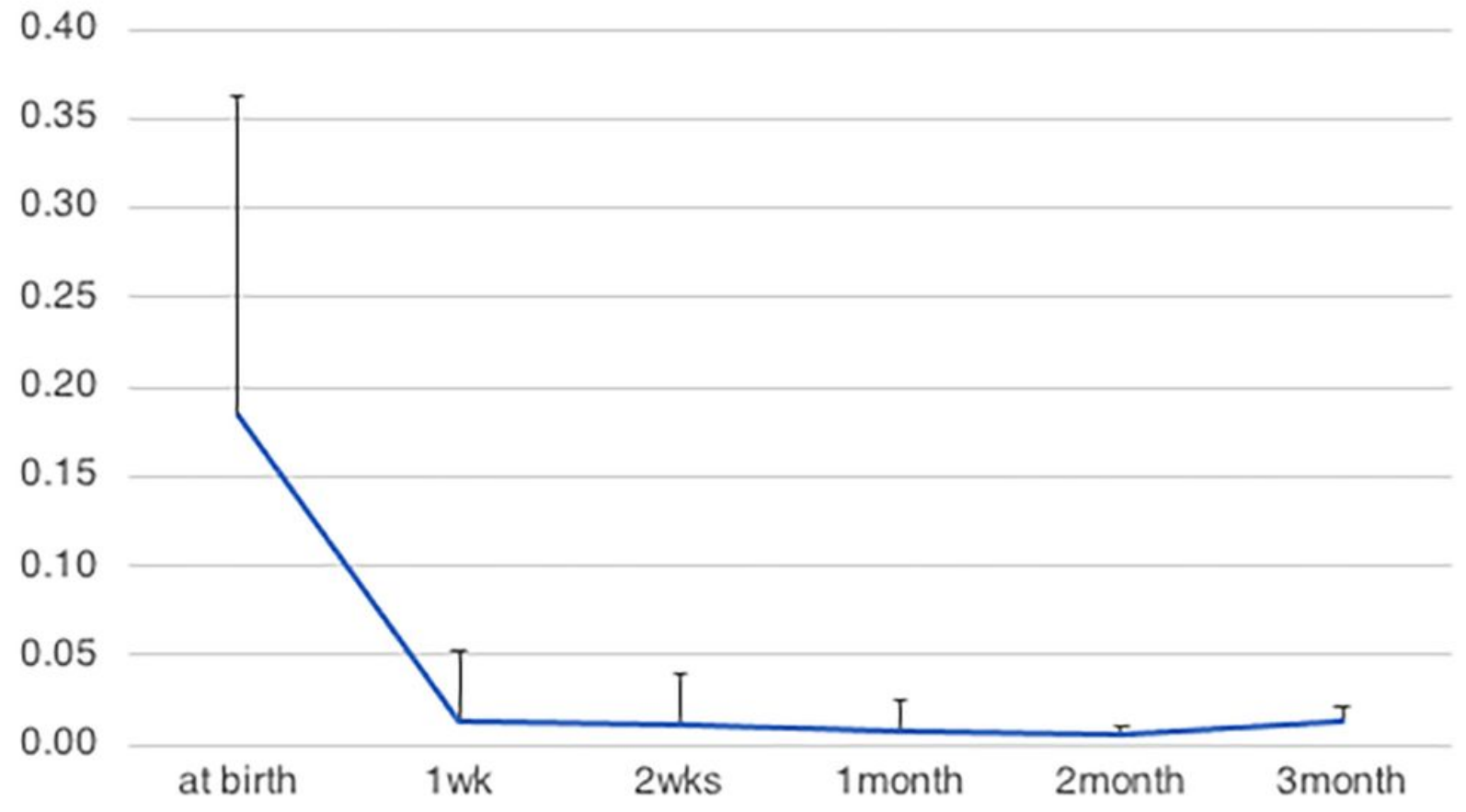

\section{Figure 1}

The receiver operating characteristic curve of hydrocortisone use and urinary tetrahydrocortisol/tetrahydrocortisone (F/E) ratio for hypotension in the early neonatal period F/E ratio were calculated as postnatal days. F/E ratio at birth was the higher level regardless gestational age, then immediately decline. 


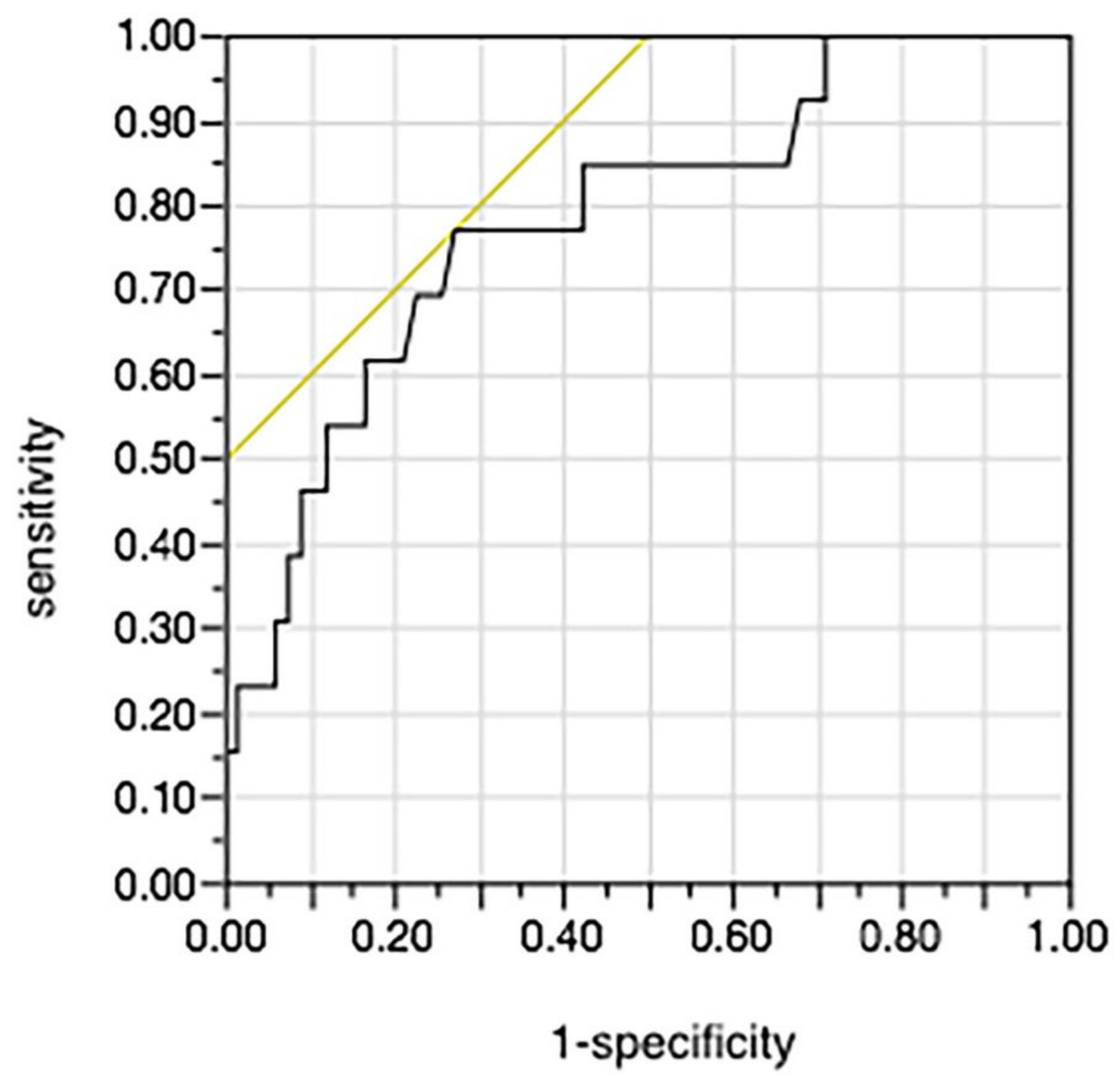

Figure 2

The receiver operating characteristic curve of hydrocortisone use and urinary tetrahydrocortisol/tetrahydrocortisone (F/E) ratio for hypotension in the early neonatal period The cut-off value of the urinary $\mathrm{F} / \mathrm{E}$ ratio at birth for hypotension requiring hydrocortisone was 0.19 , with a sensitivity of 0.7692 , specificity of 0.5035 and an area under the receiver operating characteristic curve (AUC) of 0.7826 . 